\title{
Editorial
}

\section{Rural Sustainable Environmental Management}

\author{
Chunjiang An ${ }^{1, * \mathbb{D}}$, Mengfan $\mathrm{Cai}^{1}{ }^{\text {and Christophe Guy }}{ }^{2}$ \\ 1 Department of Building, Civil and Environmental Engineering, Faculty of Engineering and \\ Computer Science, Concordia University, Montreal, QC H3G 1M8, Canada; morvan.cai@outlook.com \\ 2 Department of Chemical and Materials Engineering, Concordia University, Montreal, QC H3G 1M8, Canada; \\ christophe.guy@concordia.ca \\ * Correspondence: chunjiang.an@concordia.ca
}

Received: 13 August 2020; Accepted: 14 August 2020; Published: 18 August 2020

check for updates

\begin{abstract}
Rural environmental protection has received increasing attention in recent years. The economic development and population growth of rural areas results in many problems, such as environmental pollution, land degradation, resource depletion, biodiversity loss, income loss, and public health risks. Although much progress has been made, many major challenges to rural environmental management remain to be addressed. The question of how to deal with these problems through sustainable approaches has become an urgent issue in rural areas. This Special Issue, "Rural Sustainable Environmental Management", was dedicated to the perception of rural, sustainable environmental management based on the integration of economic, environmental, and social considerations. The Special Issue covered the topics about the rural land management and planning, sustainable rural water resources management, integrated simulation and optimization, rural environmental risk assessment and vulnerability analysis, rural water and wastewater treatment, rural environmental policy analysis, rural ecosystem protection and biodiversity recovery, and the characterization of emerging rural environmental problems and related solutions. A total of 24 high-quality papers were accepted after strict and rigorous review. These accepted papers focused on various perspectives of rural sustainable environmental management.
\end{abstract}

Keywords: rural areas; environmental management; sustainability

Rural environmental protection has received increasing attention in recent years [1,2]. The economic development and population growth of rural areas results in many problems, such as environmental pollution, land degradation, resource depletion, biodiversity loss, income loss, and public health risks [3-6]. These issues are particularly poignant in villages and remote regions of developing countries [7,8]. The rural areas often lack required resources to take needed action. In areas with low population densities and dispersed households, many management strategies associated with centralized and urban regions are unsuitable for implementation. The development of the rural economy and the protection of the environment need to be well balanced with both short- and the long-term views [9]. Of interest for rural areas are strategies that can be environmentally, socially, and economically sustainable. Although much progress has been made, many major challenges to rural environmental management remain to be addressed [10]. The question of how to deal with these problems through sustainable approaches has become an urgent issue in rural areas.

This Special Issue "Rural Sustainable Environmental Management" is dedicated to the perception of rural, sustainable environmental management based on the integration of economic, environmental, and social considerations. It provided a summary of novel developments that can improve the public awareness and provide solutions to these environmental issues. The Special Issue covers the topics about rural land management and planning, sustainable rural water resources management, integrated simulation and optimization, rural environmental risk assessment and vulnerability analysis, rural 
water and wastewater treatment, rural environmental policy analysis, rural ecosystem protection and biodiversity recovery, and the characterization of emerging rural environmental problems and related solutions. During our working period, there were many submissions. A total of 24 high-quality papers were accepted after strict and rigorous review. These accepted papers focused on various perspectives of rural sustainable environmental management.

In the aspect of rural land management and planning, Cai et al., assessed the soil and water conservation practices in the hilly region [11]. They applied a coupled rainfall-runoff-erosion model to quantify the effect of climate change and soil and water conservation practices (SWCPs) on soil and water erosion in the Loess hilly region. Compared with bare slopes, the reduction rates of different SWCPs were $15-40 \%$ for surface runoff and 35-67\% for soil erosion under different scenarios. An index called "water cost for sediment control" was also introduced to balance the runoff loss and soil erosion of each SWCP. Based on this index, the combination of shrub and horizontal terracing was recommended, because this SWCP has a smaller impact on surface runoff when reducing a similar quantity of soil erosion. Zida et al., examined the contribution of biophysical and social adaptation practices to changes in woody plant cover after the 1970s-1980s droughts, based on the collected information of geomorphology, precipitation, and soil through Landsat images, field observations, and interviews [12]. The authors proposed that the resumption of rainfall alone was not enough to explain the regreening in the Sahel after droughts, while agroforestry practices due to varying farmer perceptions played a key role. Additionally, the spatiotemporal changes of evapotranspiration in arid northern China and their effects on ecosystem management [13], the sustainable and multiple land-use planning of wetland farmland in [14], and the drivers and effects of livelihood diversification on sustainable land management practices in the upper Blue Nile Basin of Ethiopia [15], were explored to provide useful practices for rural land management and planning.

In the aspect of rural system modelling, Song et al., established an agricultural water management model based on grey water footprint theory, fractional programming, and interval programming [16]. The model can help to optimize the ratio of economic benefits to grey water footprints from crop production under uncertainty. The developed model was applied to determine the planting structure and water use of crops in the Hetao Irrigation District of China. The results can also help reduce the negative impact on the environment and enhance the economic benefits of agriculture. In another interesting article from Zhou et al., a robust linear programming method for water and environmental decision-making under uncertainty was proposed [17]. The authors also provided a regional water quality management case to demonstrate how to implement robust linear programming in real-world practice. This approach can provide decision-makers with reliable and robust management suggestions that are "immune" to the uncertainty due to data perturbations. In addition, a risk aversion based inexact stochastic dynamic programming method for water resources planning under uncertainty [18], an optimal design of a distributed energy system based on the functional interval model allowing reduction of carbon emission [19], a price-forecast-based irrigation scheduling optimization model under the response of fruit quality and price to water [20], and a multi-objective hierarchical model for irrigation planning in the complex canal system [21], were studied. These new approaches can provide more reliable and scientific advice on planting, irrigation, and energy supply, which will be favorable for the sustainable development of agriculture.

In the aspect of rural wastewater and waste management, Zamora-Castro et al., investigated the effects of three ornamental plants (Canna indica, Pontederia sagittata, and Spathiphyllum wallisii) growing in two types of filter media materials (porous river rock and tepezyl) on the removal of seasonal wastewater pollutants using fill-and-drain constructed wetlands (FD-CWs) [22]. The removal efficiency varied for different ornamental plants and a better treatment performance was observed for the use of Canna indica and Pontederia sagittate. Both filter media materials performed well in pollutant removal, especially for nitrogen and phosphorous pollutants (60-80\%). In addition, several articles explored the effect of local discharge limit legislation and appropriate financial policy on rural wastewater management [23], the forecasting of influent for wastewater treatment plants using the 
autoregressive integrated moving average (ARIMA) model [24], and the optimal location decision and flow distribution for pesticide waste management using a mixed-integer model programming method [25].

In the aspect of rural water security, Tang et al., published a paper about the safety guarantee system of drinking water source in the Three Gorges Reservoir Area [26]. A drinking water source security platform was developed with the incorporation of the two-dimensional water quality model and geographic information system (GIS). This platform was applied to simulate and visualize the migration and diffusion of ammonia nitrogen in a hypothetical leak accident. Notably, Ding et al., predicted the spatial-temporal variations of heavy metal pollution during accidents $[27,28]$. The two-dimensional water quality model and GIS were combined to predict the influence of an accident on the water source and develop corresponding emergency response strategy.

In regard to rural ecosystem protection, Atyosi and Maroyi investigated the alien plants in the Eastern Cape Province in South Africa [29]. They analyzed the information (e.g., floristic status, biological features, geographical distribution, and anthropogenic utilization) of invasive alien plant species obtained from documents and interviews. The purpose was to evaluate the public perceptions of alien plants' contributions to local livelihood needs. The results showed the public perceptions of invasive alien plants and attitudes to current management strategies on ecosystem biodiversity. In addition, several human-managed ecosystems, such as indigenous agricultural systems in the dry region of Sri Lanka [30] and grazing systems in typical Chinese and Mongolian steppes [31], were evaluated. The results suggested overwhelming human interventions could degrade ecosystem sustainability; however, appropriate management could preserve the sustainability of rural ecosystems.

For sustainable rural development, Ispas et al., introduced the environmental management practices within agritourism boarding houses (ATBHs) [32]. The study focused on small accommodation businesses in rural areas. A qualitative study was conducted based on semi-structured interviews among 12 ATBH owner-managers from Romania. The owner-managers' attitude to water and energy consumption in the tourist accommodation, as well as reasons and technologies about saving water and energy, were investigated to develop effective environmental strategies and water- and energy-saving practices in ATBHs. Moreover, the strategic assessment and economic evaluation of rural development based on an interdisciplinary multi-level decision-making approach [33], as well as the factor decomposition of the changes in unequal income in the rural regional income inequality based on the Gini index [34], were conducted for the rural areas of China. The findings in these studies can help decision makers to comprehensively consider the social, cultural, economic, and environmental factors for sustainable rural development.

Author Contributions: These authors contributed equally to this work. Their individual contributions were as follows: writing—original draft preparation, M.C. and C.A.; writing—review and editing, M.C., C.A. and C.G.; supervision, C.A. and C.G. All authors have read and agreed to the published version of the manuscript.

Funding: This research was supported by the Natural Sciences and Engineering Research Council of Canada.

Conflicts of Interest: The authors declare no conflict of interest.

\section{References}

1. Pezzagno, M.; Richiedei, A.; Tira, M. Spatial planning policy for sustainability: Analysis connecting land use and GHG emission in rural areas. Sustainability 2020, 12, 947. [CrossRef]

2. Farrow, C.; McBean, E.; Huang, G.; Yang, A.; Wu, Y.; Liu, Z.; Dai, Z.; Fu, H.; Cawte, T.; Li, Y. Ceramic water filters: A point-of-use water treatment technology to remove bacteria from drinking water in Longhai City, Fujian Province, China. J. Environ. Inform. 2018, 32, 63-68. [CrossRef]

3. Yao, Y.; Huang, G.; An, C.; Chen, X.; Zhang, P.; Xin, X.; Shen, J.; Agnew, J. Anaerobic digestion of livestock manure in cold regions: Technological advancements and global impacts. Renew. Sustain. Energy Rev. 2020, 119, 109494. [CrossRef]

4. Huang, G.; Liu, H.; Li, X.; Ma, M. Exploring drivers of nitrate contamination of drinking water in an arid region of China. J. Environ. Inform. 2019, 33, 105-112. [CrossRef] 
5. Cárdenas Alonso, G.; Nieto Masot, A. Towards rural sustainable development? Contributions of the EAFRD 2007-2013 in low demographic density territories: The case of Extremadura (SW Spain). Sustainability 2017, 9, 1173. [CrossRef]

6. Cai, M.; Xin, Z.; Yu, X. Spatio-temporal variations in PM leaf deposition: A meta-analysis. Environ. Pollut. 2017, 231, 207-218. [CrossRef]

7. Fuhrmeister, E.R.; Ercumen, A.; Pickering, A.J.; Jeanis, K.M.; Ahmed, M.; Brown, S.; Arnold, B.F.; Hubbard, A.E.; Alam, M.; Sen, D. Predictors of enteric pathogens in the domestic environment from human and animal sources in rural Bangladesh. Environ. Sci. Technol. 2019, 53, 10023-10033. [CrossRef]

8. Huang, J.; Huang, G.; An, C.; He, Y.; Yao, Y.; Zhang, P.; Shen, J. Performance of ceramic disk filter coated with nano $\mathrm{ZnO}$ for removing Escherichia coli from water in small rural and remote communities of developing regions. Environ. Pollut. 2018, 238, 52-62. [CrossRef]

9. Leakey, R.R. A re-boot of tropical agriculture benefits food production, rural economies, health, social justice and the environment. Nat. Food 2020, 1, 260-265. [CrossRef]

10. Tambovceva, T.; Atstaja, D.; Tereshina, M.; Uvarova, I.; Livina, A. Sustainability challenges and drivers of cross-border greenway tourism in rural areas. Sustainability 2020, 12, 5927. [CrossRef]

11. Cai, M.; An, C.; Guy, C.; Lu, C. Assessment of soil and water conservation practices in the loess hilly region using a coupled rainfall-runoff-erosion model. Sustainability 2020, 12, 934. [CrossRef]

12. Zida, W.A.; Bationo, B.A.; Waaub, J.P. Effects of land-use practices on woody plant cover dynamics in sahelian agrosystems in Burkina Faso since the 1970s-1980s droughts. Sustainability 2019, 11, 5908. [CrossRef]

13. Liu, J.; Xiong, Y.; Tian, J.; Tan, Z. Spatiotemporal changes in evapotranspiration from an overexploited water resources basin in arid northern China and their implications for ecosystem management. Sustainability 2019, 11, 445. [CrossRef]

14. Zhu, B.; Zhu, X.; Zhang, R.; Zhao, X. Study of multiple land use planning based on the coordinated development of wetland farmland: A case study of Fuyuan city, China. Sustainability 2019, 11, 271. [CrossRef]

15. Teshager Abeje, M.; Tsunekawa, A.; Adgo, E.; Haregeweyn, N.; Nigussie, Z.; Ayalew, Z.; Elias, A.; Molla, D.; Berihun, D. Exploring drivers of livelihood diversification and its effect on adoption of sustainable land management practices in the upper Blue Nile Basin, Ethiopia. Sustainability 2019, 11, 2991. [CrossRef]

16. Song, G.; Dai, C.; Tan, Q.; Zhang, S. Agricultural water management model based on grey water footprints under uncertainty and its application. Sustainability 2019, 11, 5567. [CrossRef]

17. Zhou, Y.; Yang, B.; Han, J.; Huang, Y. Robust linear programming and its application to water and environmental decision-making under uncertainty. Sustainability 2019, 11, 33. [CrossRef]

18. Liu, Z.; Zhou, Y.; Huang, G.; Luo, B. Risk aversion based inexact stochastic dynamic programming approach for water resources management planning under uncertainty. Sustainability 2019, 11, 6926. [CrossRef]

19. Zhu, Y.; Tong, Q.; Zeng, X.; Yan, X.; Li, Y.; Huang, G. Optimal design of a distributed energy system using the functional interval model that allows reduced carbon emissions in Guanzhong, a rural area of China. Sustainability 2019, 11, 1930. [CrossRef]

20. Shan, B.; Guo, P.; Guo, S.; Li, Z. A price-forecast-based irrigation scheduling optimization model under the response of fruit quality and price to water. Sustainability 2019, 11, 2124. [CrossRef]

21. Guo, S.; Zhang, F.; Zhang, C.; An, C.; Wang, S.; Guo, P. A multi-objective hierarchical model for irrigation scheduling in the complex canal system. Sustainability 2019, 11, 24. [CrossRef]

22. Zamora-Castro, S.A.; Marín-Muñiz, J.L.; Sandoval, L.; Vidal-Álvarez, M.; Carrión-Delgado, J.M. Effect of ornamental plants, seasonality, and filter media material in fill-and-drain constructed wetlands treating rural community wastewater. Sustainability 2019, 11, 2350. [CrossRef]

23. Wang, M.; Gong, H. Expected rural wastewater treatment promoted by provincial local discharge limit legislation in China. Sustainability 2019, 11, 2756. [CrossRef]

24. Boyd, G.; Na, D.; Li, Z.; Snowling, S.; Zhang, Q.; Zhou, P. Influent forecasting for wastewater treatment plants in North America. Sustainability 2019, 11, 1764. [CrossRef]

25. Li, Z.; Huang, J. How to effectively improve pesticide waste governance: A perspective of reverse logistics. Sustainability 2018, 10, 3622. [CrossRef]

26. Tang, X.; Zhai, A.; Ding, X.; Zhu, Q. Safety guarantee system of drinking water source in Three Gorges Reservoir area and its application in Huangjuedu drinking water source area. Sustainability 2019, 11, 7074. [CrossRef] 
27. Ding, X.; Fang, P. Accident trend prediction of heavy metal pollution in the Heshangshan drinking water source area based on integrating a two-dimensional water quality model and GIS. Sustainability 2019, 11, 3998. [CrossRef]

28. Ding, X.; Tan, Y.; Hou, B. Spatio-temporal variation of heavy metal pollution during accidents: A case study of the heshangshan protected water area, China. Sustainability 2019, 11, 6919. [CrossRef]

29. Atyosi, Z.; Ramarumo, L.J.; Maroyi, A. Alien plants in the Eastern Cape Province in South Africa: Perceptions of their contributions to livelihoods of local communities. Sustainability 2019, 11, 5043. [CrossRef]

30. Abeywardana, N.; Schütt, B.; Wagalawatta, T.; Bebermeier, W. Indigenous agricultural systems in the dry zone of Sri Lanka: Management transformation assessment and sustainability. Sustainability 2019, 11, 910. [CrossRef]

31. Na, Y.; Li, J.; Hoshino, B.; Bao, S.; Qin, F.; Myagmartseren, P. Effects of different grazing systems on aboveground biomass and plant species dominance in typical Chinese and Mongolian steppes. Sustainability 2018, 10, 4753. [CrossRef]

32. Ispas, A.; Untaru, E.N.; Candrea, A.N. Environmental management practices within agritourism boarding houses in Romania: A qualitative study among managers. Sustainability 2019, 11, 3887. [CrossRef]

33. Bottero, M.; Comino, E.; Dell'Anna, F.; Dominici, L.; Rosso, M. Strategic assessment and economic evaluation: The case study of Yanzhou Island (China). Sustainability 2019, 11, 1076. [CrossRef]

34. Xu, Y.; Qiu, X.; Yang, X.; Chen, G. Factor decomposition of the changes in the rural regional income inequality in southwestern mountainous area of China. Sustainability 2018, 10, 3171. [CrossRef]

(C) 2020 by the authors. Licensee MDPI, Basel, Switzerland. This article is an open access article distributed under the terms and conditions of the Creative Commons Attribution (CC BY) license (http://creativecommons.org/licenses/by/4.0/). 